\title{
Critical Success Factors of Supplier Selection: Findings from Social Commerce Micro-Businesses in Malaysia
}

\author{
Juwairiah Haris, Suzari Abdul Rahim, Munirah Haris, Mohd Shahir Zahari
}

To Link this Article: http://dx.doi.org/10.6007/IJARBSS/v11-i2/9193

DOI:10.6007/IJARBSS/v11-i2/9193

Received: 13 December 2020, Revised: 18 January 2021, Accepted: 31 January 2021

Published Online: 23 February 2021

In-Text Citation: (Haris et al., 2021)

To Cite this Article: Haris, J., Rahim, S. A., Haris, M., \& Zahari, M. S. (2021). Critical Success Factors of Supplier Selection: Findings from Social Commerce Micro-Businesses in Malaysia. International Journal of Academic Research in Business and Social Sciences, 11(2), 973-983.

Copyright: (c) 2021 The Author(s)

Published by Human Resource Management Academic Research Society (www.hrmars.com)

This article is published under the Creative Commons Attribution (CC BY 4.0) license. Anyone may reproduce, distribute, translate and create derivative works of this article (for both commercial and non-commercial purposes), subject to full attribution to the original publication and authors. The full terms of this license may be seen

at: http://creativecommons.org/licences/by/4.0/legalcode

Vol. 11, No. 2, 2021, Pg. 973 - 983

Full Terms \& Conditions of access and use can be found at http://hrmars.com/index.php/pages/detail/publication-ethics 


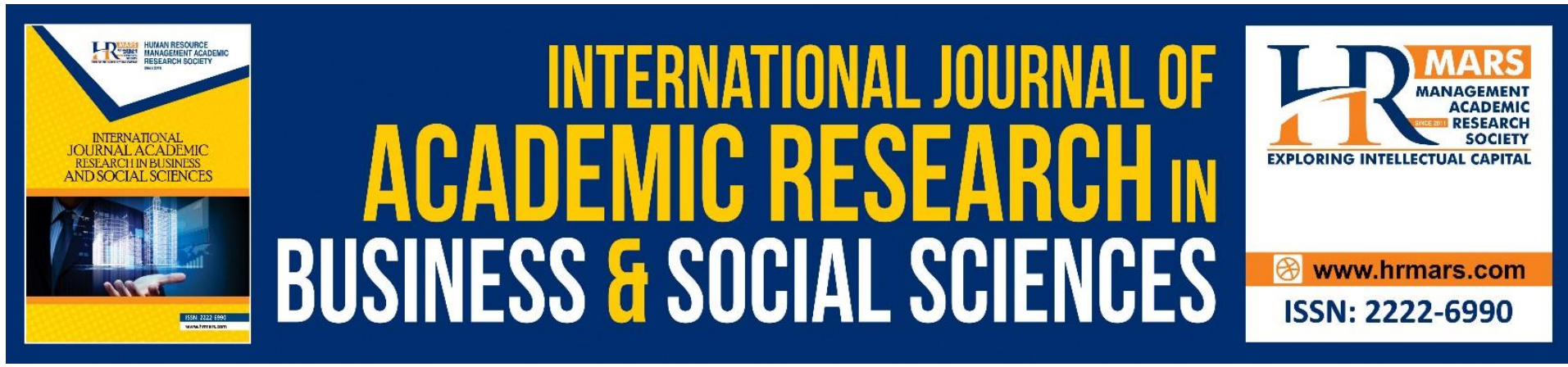

\title{
Critical Success Factors of Supplier Selection: Findings from Social Commerce Micro- Businesses in Malaysia
}

\author{
Juwairiah Haris, Suzari Abdul Rahim \\ Universiti Sains Malaysia, Malaysia \\ Munirah Haris \\ MRSM Kubang Pasu, Malaysia \\ Mohd Shahir Zahari \\ Kolej Vokasional Seberang Perai, Malaysia
}

\begin{abstract}
The purpose of this paper is to identify the critical success factors of supplier selection towards social commerce micro-businesses in Malaysia. A pilot study was carries out on a sample of 40 social commerce micro-businesses in Malaysia. A survey instrument consisting of 23 measurement items was designed to identify the level of critical factor of six supplier selection criteria implemented by social commerce micro-businesses in Malaysia. Descriptive statistical analysis and reliability analysis were used to analyse the data by using SPSS software. Findings indicated that service warranty is the most critical success factor of supplier selection by social commerce micro-businesses followed with delivery, price, quality, flexibility, and relationship. Social commerce micro-businesses should be aware of these critical success factors in social commerce industry. A limitation of this study only conducted to 40 social commerce micro-business. The study on the critical success factors of supplier selection for social commerce micro-businesses in Malaysia provides valuable know-how regarding the significance of selecting suppliers, enabling them to gain greater profits while productively performing in supply chain, higher level performance of business and further enhancement business competitive in the marketplace. This study offers important information for decision makers who are involve in supplier selection for social commerce micro-businesses and also provides useful reference for future research in this research area. Keywords: Social Commerce Micro-Businesses, Supplier Selection, Critical Success Factor, Reliability Analysis
\end{abstract}

\section{Introduction}

In the context of business, many entrepreneurs have changed or expanded their businesses from physical stores to electronic businesses to reap the benefits of this revolutionary trend of business. Sellers have more opportunities to transform and improvise their businesses by 
having online presence besides other benefits of lowering their operating cost and greater flexibility (Dong \& Wu, 2015). Not only large organisations, but smaller businesses also set up online stores to sell their products and services via social media such as Facebook, Twitter, and Instagram, known as social commerce.

Social media is one of the cheapest marketing methods incorporated in social commerce and it keeps growing every day. Based on Malaysian Communications and Multimedia Commission (MCMC) survey in 2018, there are 24.6 million social media users in Malaysia; the most famous platform is Facebook (97.3\%), followed by Instagram (57.0\%, YouTube (48.3\%), Google + (31.3\%), Twitter (23.8\%), and Linkedln (13.3\%).

Social commerce is rich with opportunities in forming new relationships and networking for anyone involved as it has the ability to create reliable participation of all parties concerning genuineness, relevancy, and transparency. Besides, using social media as one advertising strategy to collect more consumers' data is another strong point of social commerce. Everyone can post, comment, add content, share and like status updates from sellers who use social media as their business platform. Sellers, potential buyers, competitors, and other parties can communicate directly via this platform since this effective social media can provide competitive advantage among businesses and it is difficult to be replicated by competitors (Tan et al., 2014).

Noorshella et al., (2017) in their study revealed that it has become a trend among young, micro-entrepreneurs in Malaysia to utilize social media as a platform to sell products or services. Many sellers and traders from previous research have acknowledged the fact that businesses operated via online method (social commerce) are cost-saving (Razaei et al., 2014). Social commerce allows businesses to communicate directly with customers in a quick and immediate response (Veldeman, Preat \& Mechant, 2015). Also, social media sellers, in particular micro-businesses, should continuously be updated with current trend and transform information technology to keep up with their business track following the changes. This is in view of online businesses which its markets are rapidly expanding from time to time (Slater et al., 2010; Taylor \& Strutton, 2010) and this can be observed in the case of Facebook and Instagram as examples of social commerce channels.

\section{Literature Review}

Selection of supplier has become one of the main focuses in supply chain and extensively discusses since 1960 by various sources (See Dickson, 1966; Li, Madhok, Plaschka \& Verma, 2006; Yan, Chaudhry \& Chaudhry, 2003; Kannan \& Tan, 2006; Nair, Jayaram \& Das, 2015; Azadeh, Zarrin \& Salehi, 2016; Yadav \& Sharma, 2016; Kant \& Dalvi, 2017; Khalilzadeh \& Derikvand, 2018). Supplier selection is regarded as an important strategic decision for businesses (El Mokadem, 2017) and suppliers will be selected based on their ability to meet the requirements of businesses (Kar \& Pani, 2014). Supplier selection criteria is therefore crucial to be discussed in supply chain since it plays a very important role in business, affecting final price of products and services (Yadav \& Sharma, 2016). Dickson (1966) was one of the earliest researchers to provide a comprehensive overview of supplier selection criteria, identifying 23 most significant ones and ranking those criteria according to four distinguished level of importance. 
In regards of the emergence of technological advancement that is taking place all over the world, current businesses via the internet or commonly known as e-commerce have become a trend nowadays. In Malaysia, online businesses are widely acknowledged that many entrepreneurs chose the internet as a channel to start their business because they do not require significant capital. Malaysia's e-commerce market as of today shows positive development leading to new shopping trends whereby sellers (social commerce microbusinesses) and customers use social media to facilitate more efficient purchase. Customers nowadays are looking for new ways to find information about similar products through internet, purchasing them quicker and easier than conventional brick-and-mortar transactions (Mohamed, Hussein, Hidayah \& Haghshenas, 2014). In addition, fast delivery services also another reason the buyers preferred to buy online. Habidin and Yusof (2013) are of the opinion on certified quality and performance of the sellers. These benefits contribute to good responses among Malaysia to purchase online. As explained above, while selecting suppliers, social commerce micro-businesses need to emphasize their selection according to features which fulfil customers' needs. Potential suppliers should possess the required features to be selected as well as ensuring their businesses to run smoothly.

Critical success factors are one of the ways to help social commerce micro-businesses gain the information requirements in managing their businesses. Research from Fuzi et al., (2019) in their finding indicated that the critical success factors identified play as key role in ensuring the safety awareness at workplace. Similarly, critical success factors are essential to the achievement of social commerce micro-businesses' goals. Hence, this study explored the critical success factor for supplier selection of social commerce micro-businesses within the scope of Malaysia.

\section{Methodology}

This study utilized a quantitative approach to identify the critical success factors of supplier selection for Malaysia social commerce micro-businesses. This study used descriptive analysis to analyse the data. The demographic profile of respondents was classified and tabulated according to gender, race, age, state, education, status, business experience, social media channel, and the respondents' sales. Next, the questionnaire was designed to examine the critical success factors of supplier selection through the construction of 23 measurement items. A five-point Likert scales was used for each item ranging from 1 (strongly disagree) to 5 (strongly agree). A total of 23 items survey questions were designed to obtain the respondents for Malaysia social commerce micro-businesses. An expert validation was conducted to assess the validity of the content by requesting feedback consisting of comments, clarity, and quality of each item. The final draft of the questionnaire was sent to the experts.

This study was carried out before the final implementation to confirm the understanding of potential respondents toward questions and statements. Saunders et al., (2012) stated that prior to using the questionnaire to collect data it should be pilot tested. The purpose of conducting pilot test is to detect any weaknesses in the questionnaire such as ambiguous statements which then will be refined so that respondents will have no problems in answering the questions and also there will be no problems occur in recoding the data. Besides, pilot test may also help to identify the time taken to complete the survey and also other potential practical problems following the research procedure. According to Cooper and Schindler 
(2014), for quantitative approach, pilot test should comprise a group of people ranging from 25 to 100 individuals or cases. Thus, the number of 40 respondents selected for this study fulfill the requirement.

The questionnaires were distributed to 40 social commerce micro-businesses who are currently running their business via social media platforms (Facebook, Instagram, Twitter, etc) in Malaysia. The time taken for respondents to complete the questionnaire was about 15 to 20 minutes.

The data obtained from this study were analysed using SPSS. The questionnaire items were pre-coded. Thereafter, changes in the questionnaire were made based on comments and responses received from the respondents. This study provides an opportunity for the researcher to redesign the parts of the study to overcome the difficulties revealed and thus helped the researcher to reduce unexpected problems later.

\section{Result and Discussion}

From the results, all items were indicated as highly reliable with Cronbach's Alpha values more than 0.7. Nunnally and Berstein (1994) suggested that for a variable to have an acceptable level of internal consistency reliability, the Cronbach's Alpha value should be above 0.7. Sekaran (2003) supported this view that Cronbach's Alpha value more than 0.8 is considered good while within the range of 0.7 is to be acceptable and less than .6 is considered poor.

The reliability analysis for services warranty criterion presented the alpha value at 0.806 . this value of 0.806 is within the range of 0.0 to 0.9 which indicated high reliability of the six items measured on services warranty. The result of reliability analyses for the aspect of flexibility presented the alpha value at 0.787 which is within the range of 0.7 to 0.8 , and this indicates a good reliability of the six items measured on flexibility.

Reliability analysis result on delivery criterion presented the alpha value of 0.810 . since this value is within the range of 0.8 to 0.9 , it indicated a very good reliability of the six items measured in delivery. Another important finding was that the reliability analysis for relationship criterion indicates the alpha value at 0.87 . this value 0.871 is within the range of 0.8 to 0.9 , and this shows a very good reliability of the 6 items measured on relationship.

In this study, the reliability analysis for quality presented the alpha value at 0.788 . This value of 0.788 within the range of 0.7 to 0.8 , and this indicates a good reliability of the six items measured on quality. The present result of reliability analysis for price factor presented the alpha value at 0.778 . The value of 0.778 within the range of 0.7 to 0.8 , and this indicates a good reliability of the 6 items measured on price.

All reliability analysis obtained on factors of supplier selection for social commerce microbusinesses showed good alpha values and the value are within the range of 0.778 and 0.871 . In conclusion, the reliability analysis of the pilot data indicated that all the criteria selected have alpha value more than 0.7 (range from 0.778 and 0.871 ). 
INTERNATIONAL JOURNAL OF ACADEMIC RESEARCH IN BUSINESS AND SOCIAL SCIENCES Vol. 11, No. 2, 2021, E-ISSN: 2222-6990 @ 2021 HRMARS

Table 1: Average rating for critical success factors of supplier selection for social commerce micro-businesses in Malaysia.

\begin{tabular}{|c|c|c|c|}
\hline Factors & Mean & Average Mean & Rank \\
\hline \multicolumn{2}{|c|}{ Service Warranty } & \multirow{4}{*}{4.1538} & \multirow{4}{*}{1} \\
\hline SW1 & 4.2051 & & \\
\hline SW2 & 4.2308 & & \\
\hline SW3 & 4.0256 & & \\
\hline \multicolumn{2}{|c|}{ Flexibility } & \multirow{4}{*}{3.7521} & \multirow{4}{*}{5} \\
\hline F1 & 3.8205 & & \\
\hline F2 & 3.8462 & & \\
\hline F3 & 3.5897 & & \\
\hline \multicolumn{2}{|c|}{ Delivery } & \multirow{5}{*}{4.1410} & \multirow{5}{*}{2} \\
\hline D1 & 4.2564 & & \\
\hline $\mathrm{D} 2$ & 4.1795 & & \\
\hline D3 & 4.0513 & & \\
\hline D4 & 4.0769 & & \\
\hline \multicolumn{2}{|c|}{ Relationship } & \multirow{5}{*}{3.6090} & \multirow{5}{*}{6} \\
\hline R1 & 3.9231 & & \\
\hline R2 & 3.6410 & & \\
\hline R3 & 3.6410 & & \\
\hline R4 & 3.2308 & & \\
\hline \multicolumn{2}{|c|}{ Quality } & \multirow{6}{*}{4.0564} & \multirow{6}{*}{4} \\
\hline Q1 & 3.9231 & & \\
\hline Q2 & 4.0513 & & \\
\hline Q3 & 4.1795 & & \\
\hline Q4 & 4.0256 & & \\
\hline Q5 & 4.1026 & & \\
\hline \multicolumn{2}{|c|}{ Price } & \multirow{5}{*}{4.1346} & \multirow{5}{*}{3} \\
\hline P1 & 4.2051 & & \\
\hline $\mathrm{P} 2$ & 4.0769 & & \\
\hline P3 & 4.1795 & & \\
\hline P4 & 4.0769 & & \\
\hline
\end{tabular}

The overall means for all factors are obtained to identify their level of significance and tabulated in Table 1. The mean values are ranging from 3.6090 to 4.1538 which is good criteria for social commerce micro-businesses during selecting the suppliers. The two highest critical success factors of supplier selection for social commerce micro-businesses are services warranty (4.1538) and delivery (4.1410). Following these are other factors; price (4.1246), quality (4.0564), flexibility (3.7521), and relationship (3.6090).

Given the highest mean score, this analysis indicates that services warranty is the most critical success factor of supplier selection among the Malaysian social commerce micro-businesses. Klapalová (2019) stated that warranty is the obligation for producers or sellers to compensate their customers for some form of loss by repairing, replacing, or refunding it the product fails. Warranty indicates assurance if quality and durability place on the goods which is needed by business sellers especially social commerce micro-businesses who most of the time promote 
and sell their products and services online. Warranty is also known as an important contract between producers and buyers (Park \& Pham, 2010), a contract that requires manufacturers and vendors to fix problems or failures within the promised the frame (Taleizadeh \& Sherafati, 2019) which also an indication of suppliers' performance (Azadeh et al., 2016). Warranty policy offered by suppliers' company helps social commerce micro-business improving customers view towards their products reliability and therefore there is a higher possibility for social commerce micro-businesses' intention to include the suppliers with this aspect to be in their suppliers list. In this study, the aspect of warranty was proven to influence social commerce micro-businesses' intention which result in positive perceived behaviour to select suppliers.

Meanwhile, the second highest critical success factor of supplier selection criteria for social commerce micro-businesses in Malaysia is delivery. Delivery has positive impact on social commerce micro-businesses in fulfilling customers' needs and satisfaction. Studies carried out by Amin and Razmi (2009) and Ozfirat, Tasoglu and Memis (2014) showed that delivery is another important criterion after quality. Fast, on time delivery is essential for social commerce micro-businesses to ensure there is no delay of products or services experiences by the customers. Azadeh et al., (2016) supported this claim and stated that the aspect of suppliers' performance is very important, especially regarding delivery. Even though suppliers offer lower prices, it still does not benefit social commerce microbusiness if the suppliers are unreliable and their delivery performance is always problematic. Therefore, social commerce micro-businesses should not choose suppliers merely based on low prices of products and services offers; other criteria such as delivery performance is also vital to be considered. If delivery time does not comply with the order demand, it would be detrimental to social commerce micro-businesses which in the end will indirectly delay delivery process to the customers.

The next critical success factors of supplier selection for social commerce micro-businesses in Malaysia is price. Azadeh et al., (2016) opted that the aspect of price plays an importance role during supplier selection process for customers satisfaction. Sellers should always continue to improve their supply chain operations with the existing suppliers and at the same time need to add new supplies, so that their business will always running smoothly following the latest market demand. For this to happen, social commerce micro-businesses need to find suppliers that can provide low prices for products or services. Another critical success factor social commerce micro-business needs to make sure is the items retrieved from the suppliers should have quality features. This is supported by Amin and Razmi (2009) who argued that the main important point to note when sellers deal with suppliers is user-based. It is very important for social commerce micro-businesses to sell what customers want since high demand for quality products usually will promise fruitful opportunity for social commerce micro-businesses to succeed. Thus, if suppliers can provide the best quality of products and services, they have the tendency to be listed in the social commerce micro-businesses' suppliers lists.

Flexibility is defined as ones' ability to adapt to changes yet in the meantime able to maintain their performance (Yadav \& Sharma, 2016). In the view of Schoenherr et al., (2012) stated that flexibility is an importance strategy for organisations to survive in the long term and achieve superior performance compared to their competitors, thus looking for suppliers with 
flexibility criterion is important (Ho, Xu \& Dey, 2010). This aspect is extremely crucial since social commerce micro-businesses require highly flexible suppliers which can suit their online business in any circumstances. Chiang, Kocabasoglu-Hillmer and Suresh (2012) pointed out one possible way to address problems in supplier selection and business performance is by looking at suppliers' flexibility because this aspect can build expedient attribute and create a healthy working environment. A good flexibility shows the ability of the company and at the same time reduce the likelihood of untoward things from happen (Kortmann, Gelhard, Zimmermann \& Piller, 2014).

From the findings, the least critical factors of supplier selection for social commerce microbusinesses in Malaysia is relationship. Relationship between supplier and retailers are imperative and Lai et al., (2015) stated that strong collaborative relationships can enhance communication among suppliers and buyers-seller. In businesses, social commerce microbusinesses can build relationships with suppliers through various transactions. Normally, these relationships occur if social commerce micro-businesses are satisfied with good deals and offers from suppliers thus perception shaped from the interaction may potentially influence their behavioural intention to choose the suppliers. Social commerce microbusinesses' acceptance towards different suppliers is also different according to their motivation, vision, and direction of business deals. Relationship does not only depend on period of business deals and behavioural intention to obtain the supply, buy it should also be in line with the sellers' intention to continue conducting transactions with suppliers (Deb, 2014).

The results of this study indicate that six critical success factors of supplier selection are valid and reliable to be considered by Malaysian social commerce micro-businesses during selecting suppliers. Based on the result, services warranty is the most critical factor which contributes to the success of social commerce micro-businesses in the country and therefore should be considered during supplier selection to enhance social commerce microbusinesses' performance.

\section{Conclusion}

Based on the reliability analysis, all six factors of supplier selection namely service warranty, delivery, price, quality, flexibility, relationship are significant in this study; the result indicated services warranty to be the most critical determinant of supplier selection for social commerce micro-businesses in Malaysia. The study provides some practical benefits which hopefully will give some insights and improve knowledge and performance of social commerce micro-businesses in Malaysia. The study on the factors that influence supplier selection of social commerce micro-businesses in Malaysia provides valuable know-how regarding the significance of selecting suppliers, enabling business sellers to gain greater profits while productively performing in the supply chain. The results of this study can also be applied by social commerce micro-businesses in Malaysia to improvise their objectives and future direction. For future research, it is suggested to involve larger respondents and consider exploring other supplier selection criteria that can potentially affect the performance of social commerce micro-businesses in Malaysia. This study helps customers (social commerce micro-businesses) to identify behaviour of the manufacturers (suppliers) so they can design new plans and implementation in their market strategies. 


\section{Acknowledgement}

We would like to extend our gratitude to the people involved in conducting this study. Deepest appreciation to the faculty and university for the trust given as well as thanks to our family and friends who have supported us all this time.

\section{Corresponding Author}

Juwairiah binti Haris

Graduate School of Business, Universiti Sains Malaysia, Malaysia.

Email: shahriah@gmail.com

\section{References}

Amin, S. H., \& Razmi, J. (2009). An integrated fuzzy model for supplier management: A case study of ISP selection and evaluation. Expert Systems with Applications, 36(4), 86398648.

Azadeh, A., Zarin, M., \& Salehi, N. (2016). Supplier selection in closed loop supply chain by an integrated simulation-Taguchi-DEA approach. Journal of Enterprise Information Management, 29(3), 302-326.

Chiang, C. Y., Kocabasoglu-Hillmer. C., \& Suresh, N. (2012). An empirical investigation of the impact of strategic sourcing and flexibility on firm's supply chain agility. International Journal of Operations \& Production Management, 32(1), 49-78.

Cooper, D. R., \& Schindler, P. S. (2014). Business Research Methods (12th ed.). New York, Pearson

Deb, M. (2014). A study on the factors governing retailer-customer long term relationship. International Journal of Commerce and Management, 24(3), 257-272.

Dickson, G. (1966). An Analysis of Vendor Selection Systems and Decisions. Journal of Purchasing, 2(1), 5-17.

Dong, J. Q., \& Wu, W. (2015). Business value of social media technologies: Evidence from online user innovation communities. Journal of Strategic Information Systems, 24(2), 113-127.

El Mokadem, M. (2017). The classification of supplier selection criteria with respect to lean or agile manufacturing strategies. Journal of Manufacturing Technology Management, 28(2), 232-249.

Fuzi, N. M., Habidin, N. F., Janudin, S., \& Ong, S. (2019). Critical success factors of environmental management accounting practices: Findings from Malaysian manufacturing industry. Measuring Business Excellence, 23(1), 1-14.

Habidin, N. F., \& Yusof, S. M. (2013). Critical success factors of Lean Six Sigma for the Malaysian automotive industry. International Journal of Lean Six Sigma, 4(1), 60-82.

Ho, W., Xu, X., \& Dey, P. K. (2010). Multi-criteria decision-making approaches for supplier evaluation and selection: A literature review. European Journal of Operational Research, 202(1), 16-24.

Kannan, V. R., \& Tan, K. C. (2006). Supplier selection and assessment: Their impact on business performance. Journal of Supply Chain Management, 38(4), 11-21.

Kant, R., \& Dalvi, M. V. (2017). Development of questionnaire to assess the supplier evaluation criteria and supplier selection benefits. Benchmarking: An International Journal, 24(2), 359-383.

Kar, A., \& Pani, A. K. (2014). Exploring the importance of different supplier selection criteria. Management Research Review, 37(1), 89-105. 
Khalilzadeh, M., \& Derikvand, H. (2018). A multi-objective supplier selection model for green supply chain network under uncertainty. Journal of Modelling in Management, 13(3), 605-625.

Klapalová, A. (2019). Customer product returns - feedback and knowledge management. Measuring Business Excellence, 23(2).

Kortmann, S., Gelhard, C., Zimmermann, C., \& Piller, F. T. (2014). Linking strategic flexibility and operational efficiency: The mediating role of ambidextrous operational capabilities. Journal of Operations Management, 32(7/8), 475-490.

Lai, C-S., Chan, D. Y-C., Yang, C-F., \& Hsu, W-C. (2015). The value creation scale of supplierdistributor relationship in international markets. Journal of Business \& Industrial Marketing, 30(2), 171-181.

Li, S., Madhok, A., Plaschka, G., \& Verma, R. (2006). Supplier-switching inertia and competitive asymmetry: A demand-side perspective. Decision Sciences, 37(4), 547-76.

Malaysian Communications and Multimedia Commission. (2018). Internet Users Survey 2018. Retrieved 2019, Mac 15 from https://www.mcmc.gov.my/skmmgovmy/media /General/pdf/Internet-Users-Survey-2018.pdf

Mohamed, N., Hussein, R., Hidayah. N. A. Z., \& Haghshenas, H. (2014). Insights into individual's online shopping continuance intention. Industrial Management \& Data Systems, 114(9),1453-1476.

Nair, A., Jayaram, J., \& Das, A. (2015). Strategic purchasing participation, supplier selection, supplier evaluation and purchasing performance. International Journal of Production Research, 53(20), 6263-6278.

Noorshella, C., Mamun, A., Nasir, N., Shokery, N., Raston, N., \& Fazal, S. (2017). Acceptance and usage of social media as a platform among student entrepreneurs. Journal of Small Business and Enterprise Development, 24(2), 375-393.

Nunnally, J. C., \& Berstein, M. (1994). Psychometric Theory, 3rd (ed). New York: McGraw Hill.

Ozfirat, P. M., Tasoglu, G. T., \& Memis, G. T. (2014). A fuzzy analytic hierarchy process methodology for the supplier selection problem. Journal of Enterprise Information Management, 27(3), $292-301$.

Park, M., \& Pham, H. (2010). Altered quasi-renewal concepts for modelling renewable warranty costs with imperfect repairs. Mathematical and Computer Modelling, 52, 1435-1450.

Razaei, S., Amin, M., Khairuzzaman, W., \& Ismail, W. (2014). Online repatronage intention: An empirical study among Malaysian experienced online shoppers. International Journal of Retail \& Distribution Management, 42(5), 390-421.

Saunders, M., Lewis, P., \& Thornhill, A. (2012). Research Methods for Business Students. Harlow, Pearson Education Ltd.

Schoenherr, T., Modi, S. B., Benton, W. C., Carter, C. R., Choi, T. Y., Larson, P. D., Leenders, M. R., Mabert, V. A., Narasimhan, R., \& Wagner, S. M. (2012). Research opportunities in purchasing and supply management. International Journal of Production Research, 50(16), 4556-4579.

Sekaran, U. (2003). Research methods for business: A skill-building approach. New York: John Wiley \&Sons.

Slater, S. F., Hult, G. T. M., \& Olson, E. M. (2010). Factors influencing the relative importance of marketing strategy creativity and marketing strategy implementation effectiveness. Industrial Marketing Management, 39(4), 551-559. 
Taleizadeh, A., \& Sherafati, M. (2019). A three-level supply chain with warranty services, pricing and marketing decisions: Competition and cooperation analysis. Journal of Modelling in Management, 14(3).

Tan, C., Li, Y., Pereira, C. A. P., García, M. I., Fabiola, G. R. Z., \& Contreras-Espinosa, R. S. (2014). The importance of Facebook as an online social networking tool for companies. International Journal of Accounting \& Information Management, 22(4), 295-320.

Veldeman, C., Praet, E. V., \& Mechant, P. (2015). Social Media Adoption in Business-toBusiness: IT and Industrial Companies Compared. International Journal of Business Communication, 54(3), 283-305.

Yadav, V., \& Sharma, M. K. (2016). Multi-criteria supplier selection model using the analytic hierarchy process approach. Journal of Modelling in Management, 11(1), $326-354$.

Yan, J., Chaudhry, P., \& Chaudhry, S. (2003). A model of a decision support system based on case-based reasoning for third-party logistics evaluation. Expert Systems, 20(4), 196207. 